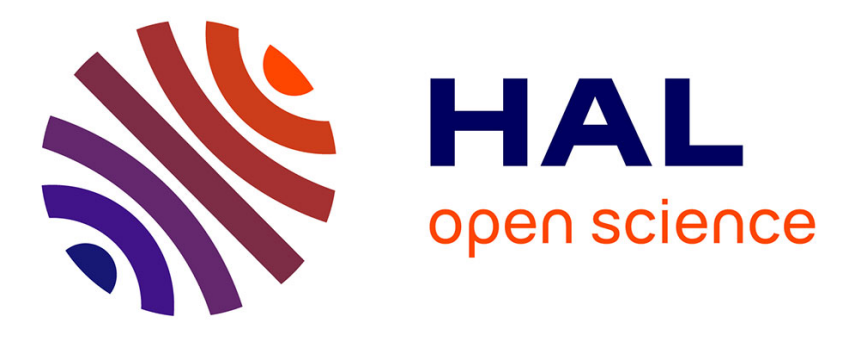

\title{
LecA (PA-IL), a Galactose-Binding Lectin from Pseudomonas aeruginosa
}

Sakonwan Kuhaudomlarp, Émilie Gillon, Annabelle Varrot, Anne Imberty

\section{To cite this version:}

Sakonwan Kuhaudomlarp, Émilie Gillon, Annabelle Varrot, Anne Imberty. LecA (PA-IL), a GalactoseBinding Lectin from Pseudomonas aeruginosa. Methods in Molecular Biology, 2020, Lectin purification and analysis, 2132, pp.257-266. 10.1007/978-1-0716-0430-4_25 . hal-02554317

\section{HAL Id: hal-02554317 https://hal.science/hal-02554317}

Submitted on 25 Apr 2020

HAL is a multi-disciplinary open access archive for the deposit and dissemination of scientific research documents, whether they are published or not. The documents may come from teaching and research institutions in France or abroad, or from public or private research centers.
L'archive ouverte pluridisciplinaire HAL, est destinée au dépôt et à la diffusion de documents scientifiques de niveau recherche, publiés ou non, émanant des établissements d'enseignement et de recherche français ou étrangers, des laboratoires publics ou privés. 


\title{
LecA (PA-IL), a Galactose-Binding Lectin from Pseudomonas aeruginosa
}

\author{
Sakonwan Kuhaudomlarp, Emilie Gillon, Annabelle Varrot \& Anne Imberty* \\ Univ. Grenoble Alpes, CNRS, CERMAV, 38000 Grenoble, Alpes \\ *Author for correspondence: Anne Imberty, anne.imberty@cermav.cnrs.fr
}

\section{Running Head : LecA/PA-IL from Pseudomonas aeruginosa}

Key words: Lectins, Protein-Carbohydrate Interactions, X-ray crystallography, Surface Plasmon Resonance, Pseudomonas aeruginosa

\begin{abstract}
LecA/PA-IL (Pfam PF07828) is a soluble galactose-binding lectin from bacterium Pseudomonas aeruginosa. The lectin is specific for $\alpha$-galactose present on glycosphingolipids of the globoside family and has therefore been proposed to play a role in cell adhesion and in internalization of bacteria in epithelial cells. The lectin has also direct toxic activity. Search for high affinity inhibitors can be performed on the recombinant lectin, with use of surface plasmon resonance assays and structural studies.
\end{abstract}

\section{Introduction}

Pseudomonas aeruginosa is a Gram-negative bacterium and a leading pathogen responsible for acute as well as chronic infections of immune-compromised patients and patients suffering from cystic fibrosis [1]. Among other virulent factors, $P$. aeruginosa produces LecA, a calcium-dependent galactose-specific soluble lectin, also referred to as PA-IL [2], the production of which is regulated by quorum sensing [3]. LecA was initially identified and characterized in the cytoplasm of $P$. aeruginosa but large quantities are present on the outer membrane of the bacterium, suggesting it may play a role in adhesion [4]. LecA is involved in biofilm development [5]. It also has strong cytotoxic effect and has been demonstrated to induce permeability effect in epithelial cells, resulting in injury in lungs [6] and intestines [7]. The lectin is specific for globosides, i.e. glycosphingolipids terminated by an $\alpha$-galactose $(\alpha-$ Gal) residue. The interaction with cell membrane glycolipids result in signalling through protein phosphorylation [8] and bacteria intracellular invasion through membrane invagination [9].

(A)

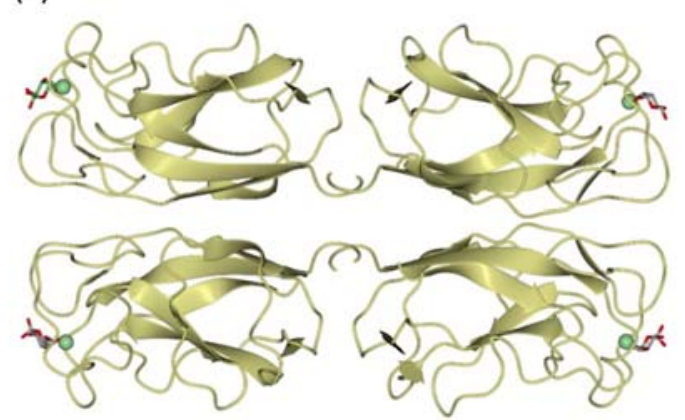

(B)

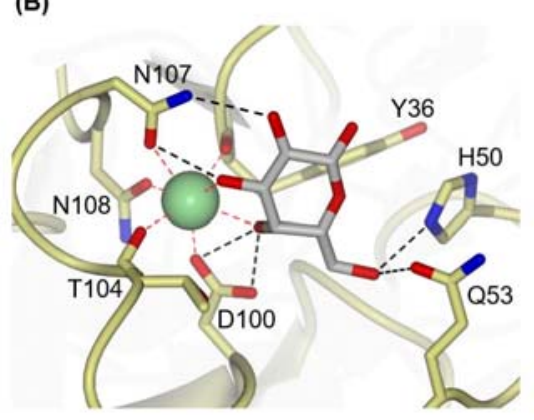

Figure 1. Crystal structure of LecA in complex with Gal. (A) The overall structure of LecA tetramer in complex with Gal. The protein backbone of a tetrameric LecA is shown in cartoon representation (yellow), Gal is shown as grey cylinders and calcium ion as green spheres. (B) The Gal binding site in a LecA monomeric subunit. Hydrogen bonds are shown in black dash lines and contacts with calcium ion in red dash lines. Calcium is represented as a light green sphere and Gal in grey cylinder. 
The lectin LecA (51 kDa) is composed of four subunits of 121 amino acids. Its binds to $\alpha$-Gal monosaccharide and terminal $\alpha-\mathrm{Gal}$ on oligosaccharides with moderate $\mu \mathrm{M}$ affinity [10]. The presence of aromatic group on the sugar anomeric position, either in $\alpha$ or $\beta$ configurations, yield to higher affinity, with $K_{\mathrm{D}}$ of $5 \mu \mathrm{M}$ for $\beta$-galactosides through $\mathrm{CH}-\pi$ interaction between His50 and the aromatic ring of the galactoside aglycone [11].

The first X-ray structure of LecA in complex with $\alpha$-Gal and calcium was reported in 2003 (Fig. 1) [12], which has since provided a solid framework for the successive development of inhibitors against LecA and subsequently $P$. aeruginosa infection, in particular the development of aromatic glycoside inhibitors [11,13], multivalent galactoside inhibitors [1419] and a covalent inhibitor targeting the carbohydrate binding site in LecA [20]. Moreover, a structure of LecA in complex with melibiose ( $\alpha$ Gall-6Glc) unravelled a secondary binding site that could be used as an additional target for inhibitor design [21].

\section{Materials}

\subsection{Gene Sequence}

GenBank ID:NP_251260.1|PA-I galactophilic lectin [Pseudomonas aeruginosa PAO1].

\subsection{Protein production in Escherichia coli}

1. BL21 (DE3) competent cells.

2. Lysogeny broth (LB) (Invitrogen) and LB agar containing $100 \mu \mathrm{g} / \mathrm{mL}$ ampicillin

3. Isopropyl $\beta$-D-1-thiogalactopyranoside (IPTG).

\subsection{Protein Purification}

1. Pierce $\mathrm{TM}^{\mathrm{TM}} \mathrm{D}$-galactose agarose column (ThermoFisher).

2. $\mathrm{NGC}^{\mathrm{TM}}$ Chromatography System (BIO-RAD) with ChromLab software.

3. One Shot Cell disruptor (Constant Systems Ltd, UK).

4. Buffer A (20 mM Tris-HCl pH 7.5, $\left.100 \mathrm{mM} \mathrm{NaCl}, 100 \mu \mathrm{M} \mathrm{CaCl}_{2}\right)$. (see Note 1)

5. Buffer B (20 mM Tris-HCl pH 7.5, 100 mM NaCl, 100 mM EDTA).

\subsection{Surface Plasmon Resonance:}

1. BIACORETM X100 SPR system (GE Healthcare).

2. BIACORE sensor chip CM5 (GE Healthcare).

3. $1 \times$ PBS-P+ $(10 \mathrm{mM}$ phosphate buffer, $2.7 \mathrm{mM} \mathrm{KCl}, 0.137 \mathrm{M} \mathrm{NaCl}, 0.05 \%$ Tween-20, 0.1 $\mathrm{mM} \mathrm{CaCl} 2)$.

4. $10 \mathrm{mM}$ acetate buffer $\mathrm{pH} 4.5$.

5. $1 \times$ PBS buffer containing $100 \mu \mathrm{M} \mathrm{CaCl}_{2}$.

6. 4-nitrophenyl $\beta$-D-galactopyranoside ( $\beta$-pNP-Gal, MW 301.25, Sigma-Aldrich).

7. Amine Coupling Kit (GE Healthcare) containing 1-ethyl-3-(3dimethylaminopropyl)carbodiimide hydrochloride (EDC) $(750 \mathrm{mg}), \mathrm{N}$-hydroxysuccinimide (NHS) $(115 \mathrm{mg})$, and ethanolamine- $\mathrm{HCl} \mathrm{pH} 8.5(1 \mathrm{M}, 10.5 \mathrm{ml})$ in separate vials.

\subsection{Protein Crystallisation}

1. 24 or 48 wells VDX Plate with sealant 24 well (Hampton Research) or SuperClear ${ }^{\mathrm{TM}}$, pregreased 24 well plates (Jena Bioscience).

2. Siliconized glass circle cover slides ( $22 \mathrm{~mm}$, Hampton research).

3. Crystallisation solution for LecA in complex with Gal (1.5 M ammonium sulfate, $100 \mathrm{mM}$ sodium acetate $\mathrm{pH} 4.7,5 \%$ 2-methyl-2,4-pentanediol (MPD) and 2\% glycerol). (see Note 2)

4. D-galactose (Gal, MW 180.16, Sigma-Aldrich). 


\section{Methods}

\subsection{LecA Production}

\subsubsection{Transformation and Preculture}

1. The gene encoding LecA was obtained from template DNA from Pseudomonas aeruginosa ATCC 15692. The gene was successfully ligated into an expression vector pET25b to create a recombinant plasmid called pET25b-PAIL, which is available upon request.

2. $1 \mu \mathrm{L}$ of the pET25b-PAIL plasmid was mixed with $100 \mu \mathrm{L}$ of competent BL21(DE3) cells, followed by incubation on ice for $10 \mathrm{~min}$.

3. The plasmid was transformed into the competent cells by heat shock at $42^{\circ}$ for $45 \mathrm{~s}$, then rest on ice for $3 \mathrm{~min}$.

4. The transformed cells were inoculated in $900 \mu \mathrm{L}$ liquid $\mathrm{LB}$ and incubated for $1 \mathrm{~h}$ at $37^{\circ} \mathrm{C}$ with agitation at $180 \mathrm{rpm}$.

5. $100 \mu \mathrm{L}$ of the liquid culture was spread on LB agar containing $100 \mu \mathrm{g} / \mathrm{ml}$ ampicillin and incubated at $37^{\circ} \mathrm{C}$ overnight to select for cells containing the recombinant plasmid.

6. In order to prepare precultures, cell colonies containing the recombinant plasmid were inoculated in $10 \mathrm{~mL}$ liquid LB containing $100 \mu \mathrm{g} / \mathrm{mL}$ ampicillin and incubated at $37{ }^{\circ} \mathrm{C}$ overnight with agitation at $180 \mathrm{rpm}$.

\subsubsection{Culture}

1. $2.5 \mathrm{~mL}$ of the preculture was transferred into 1 litre of liquid LB containing $100 \mu \mathrm{g} / \mathrm{mL}$ ampicillin.

2. The 1-litre culture was incubated at $37^{\circ} \mathrm{C}$ with agitation at $180 \mathrm{rpm}$ until $\mathrm{OD}_{600}$ of 0.6 was reached.

3. The expression of LecA was induced by adding $0.5 \mathrm{mM}$ IPTG to the culture, then further incubated at $30^{\circ} \mathrm{C}$ for 3 hours with agitation at $180 \mathrm{rpm}$.

4. The cells were harvested by centrifugation $\left(6000 \times g, 4{ }^{\circ} \mathrm{C}, 10 \mathrm{~min}\right)$, then re-suspended in liquid LB and centrifuged again in $50 \mathrm{~mL}$ falcons at $6000 \mathrm{x}$ g for $10 \mathrm{~min}$.

5. The pellets were stored at $-20^{\circ} \mathrm{C}$ until required.

\subsubsection{LecA Purification by Affinity Chromatography}

1. The cell pellet from 1L of culture was re-suspended in $30 \mathrm{~mL}$ of Buffer A supplemented with $1 \mu \mathrm{l}$ of benzonase and incubated at room temperature for 10 minutes.

2. The cells were lysed by a cell disruptor at $1.9 \mathrm{kbar}$.

3. The lysate was centrifuged $\left(24,000 \mathrm{x} \mathrm{g}, 30 \mathrm{~min}, 4{ }^{\circ} \mathrm{C}\right)$. The supernatant was filtered with $0.45 \mu \mathrm{m}$ syringe filter.

4. D-Gal agarose 5-mL column was pre-equilibrated with Buffer A (3 column volumes, 3 $\mathrm{mL} / \mathrm{min}$ ).

5. The filtered supernatant containing LecA was injected onto the pre-equilibrated column at low flow to promote interaction of LecA with Gal on the column.

6. The column was washed with Buffer A to remove unbound proteins (approximately $3 \mathrm{CVs}$ or until Abs280 reached 0).

7. Bound LecA protein was eluted with $100 \%$ Buffer B and collected as 5-mL fractions.

8. The column was rinsed with milliQ water $+0.02 \%$ sodium azide and stored in $20 \%$ ethanol.

9. The collected protein fractions were combined and dialyzed in $5 \mathrm{~L}$ of milliQ water for 3 days at $4{ }^{\circ} \mathrm{C}$ while changing the water twice per day. The dialysed protein was lyophilized and stored at $-20^{\circ} \mathrm{C}$ until required. (see Note 3 ) 


\subsection{Surface Plasmon Resonance (SPR)}

SPR is a label-free analytical technique for detecting intermolecular interactions between an analyte in solution and an immobilised ligand on the SPR sensor surface. The method is based on the change in the refractive index of the biosensor surface, which occurs when the analyte interacts with the immobilised ligand. SPR has a broad range of sensitivity detection (nM-mM) and requires relatively small quantity of samples per analysis. SPR has been used for analysis of various protein-carbohydrate interactions [22]. SPR experiments enable thermodynamics (i.e. dissociation constant, $\left.K_{\mathrm{D}}\right)$ and/or kinetics parameters $\left(k_{\text {on }}\right.$ and $\left.k_{\text {off }}\right)$ to be determined. We have previously demonstrated the use of SPR for characterisation of LecA and their prospective glycomimetics compounds [16, 17, 23]. Herein, we provided a methodology for preparation of immobilised LecA biosensor surface and an example of SPR analysis of an interaction between immobilised LecA and a glycomimetic compound.

\subsubsection{Sample Preparation}

1. Prepare LecA solution from the lyophilized protein powder (approx. $2 \mathrm{mg}$ ) from section 3.1.3 in $500 \mu \mathrm{L}$ of $1 \times$ PBS buffer containing $100 \mu \mathrm{M} \mathrm{CaCl}_{2}$.

2. Centrifuge the solution at $7000 \times g(5 \mathrm{~min})$ to remove precipitated protein.

3. Determine the protein concentration in the supernatant in $\mathrm{mg} / \mathrm{mL}$ using absorbance at 280 $\mathrm{nm}$ (absorbance coefficient of LecA is 2.191). The concentration should be at least 1 $\mathrm{mg} / \mathrm{mL}$. From this stock solution, prepare $500 \mu \mathrm{L}$ of $100 \mu \mathrm{g} / \mathrm{mL}$ LecA in $10 \mathrm{mM}$ acetate buffer $\mathrm{pH}$ 4.5. (see Note 4)

4. Prepare $100 \mu \mathrm{L}$ of $0.1 \mathrm{mM}$ solution of $\beta-p N P-G a l$ in $1 \times$ PBS-P+. (see Note 5 )

5. Add $10 \mathrm{~mL}$ filtered milliQ water into EDC and NHS vials from GE Healthcare to dissolve the compounds. Store them separately at $-20{ }^{\circ} \mathrm{C}$ in Eppendorf tubes as $100 \mu \mathrm{L}$ aliquots until required.

\subsubsection{LecA Immobilisation on SPR Chip Using Amine Coupling Method}

1. Pre-equilibrate BIACORE X100 SPR system with $1 \times$ PBS-P + and dock a new CM5 chip. Set up a manual run on BIACORE X100 Control software and the temperature of the system at $25{ }^{\circ} \mathrm{C}$. $1 \mathrm{x}$ PBS-P + is used as a running buffer for chip activation, LecA immobilization and subsequent analyses.

2. Mix thoroughly an equal volume of EDC and NHS in an SPR tube (a minimum volume required for one injection is $130 \mu \mathrm{L})$. Ensure that there is no air bubble formed in the solution. (see Note 6)

3. Inject the EDC/NHS mixture at $10 \mu \mathrm{L} / \mathrm{min}$ with a contact time of $540 \mathrm{~s}$ to activate the docked CM5 chip (both on flow cell 1 and 2). Follow the change in the response on sensorgram during the injection. Repeat this step until the response relative to the preinjection baseline is 100-400 resonance units (RU).

4. Fix LecA on the activated surface on flow cell 2 only by injecting $100 \mu \mathrm{g} / \mathrm{mL}$ LecA in 10 $\mathrm{mM}$ acetate buffer $\mathrm{pH} 4.5$ at $10 \mu \mathrm{L} / \mathrm{min}$ with a contact time of $540 \mathrm{~s}$. Repeat this step until the response relative to the baseline reaches $\sim 10,000 \mathrm{RU}$.

5. Inject $1 \mathrm{M}$ ethanolamine- $\mathrm{HCl} \mathrm{pH} 8.5$ at $10 \mu \mathrm{L} / \mathrm{min}$ with a contact time of $540 \mathrm{~s}$ on flow cell 1 and 2 to deactivate remaining active groups and remove non-covalently bound LecA. Flow cell 1 is referred to as a reference flow cell (no LecA) and flow cell 2 as an active flow cell (containing LecA).

6. $\beta$-pNP-Gal was used as a positive control to monitor the activity of immobilized LecA on the CM5 chip prior to analysis of analytes of interest. $K_{\mathrm{D}}$ of $\beta$-pNP-Gal was previously reported as $26.1 \mu \mathrm{M}$ [13], which is sufficiently good for its use as a positive control. Figure 2 shows a typical sensorgram response after an injection of $0.1 \mathrm{mM} \beta$-pNP-Gal at 30 $\mu \mathrm{L} / \mathrm{min}$ flow rate with a contact time of $30 \mathrm{~s}$ and dissociation time of $60 \mathrm{~s}$. 


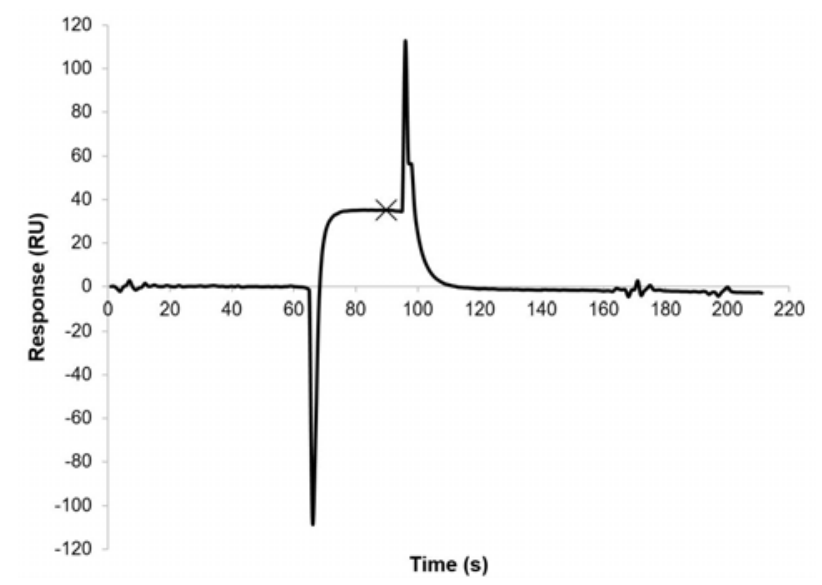

Figure 2. A typical sensorgram for $\beta$-pNP-Gal. The analyte was injected at the flow rate of 30 $\mu \mathrm{l} / \mathrm{min}$ with a contact time of $30 \mathrm{~s}$ and dissociation time of $60 \mathrm{~s}$. The report point for the binding response was automatically detected by BIACORE X100 control software when the equilibrium is reached (in this case, at $88 s$ as indicated by a cross). The spikes indicate the buffer mismatches caused by the analyte.

7. For determination of kinetic or affinity parameters, multiple injections of a range of concentrations of an analyte of interest are required. Fig. 3A represents an example of multiple cycle kinetic experiment of compound 1 (60 s contact time and $60 \mathrm{~s}$ dissociation time, flow rate $=30 \mu \mathrm{L} / \mathrm{min}$ ). The sensorgram for compound 1 has a square-like shape, indicating very fast association and dissociation of the compound from immobilised LecA, which hindered the determination of the kinetic parameters. However, the binding response and $K_{\mathrm{D}}$ could be determined by plotting the binding responses at equilibrium against the corresponding analyte concentrations (Fig. 3B). (see Note 7)

(A)
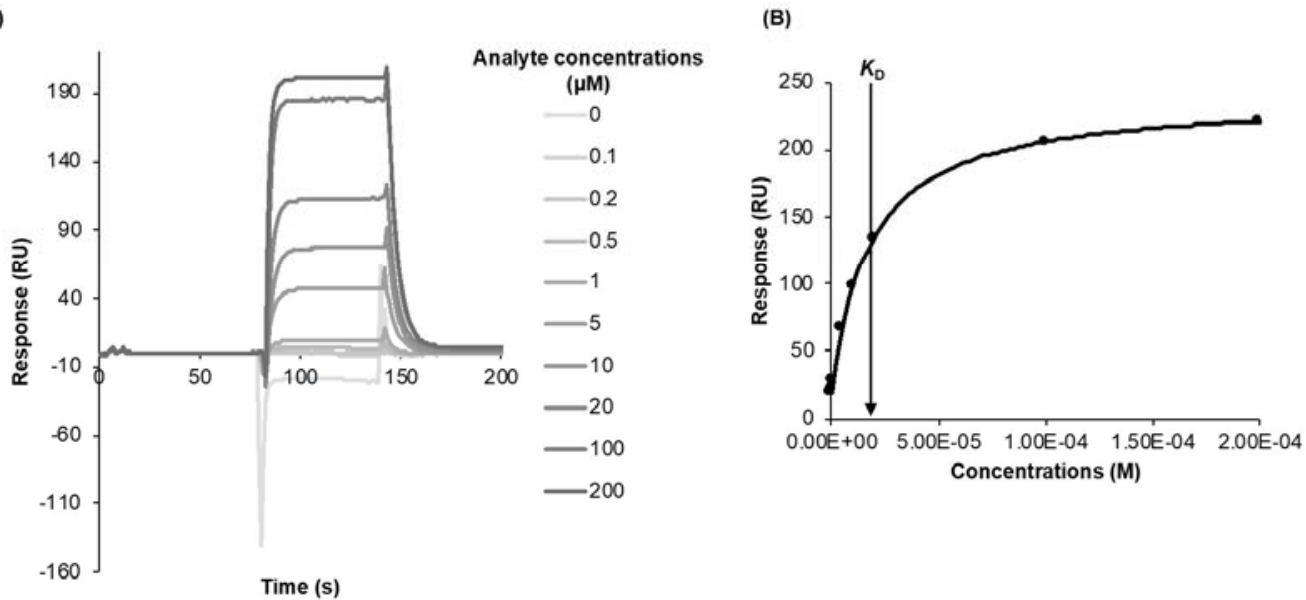

Figure 3. A multicycle kinetic experiment for compound $\mathbf{1}$ for determination of $K_{D}$. (A) Sensorgrams of multicycle injections of a range of concentrations of compound 1 . (B) The binding responses that were determined from the sensorgrams in (A) were plotted against the compound concentrations. $K_{D}$ is determined as the concentration at which half of the maximum response is reached 


\subsection{LecA Crystallisation}

We demonstrated below a detailed methodology for co-crystallisation of LecA with Gal following our previously published protocol from Cioci et al. [12], which reported the first structure of LecA in complex with Gal (PDB code 1OKO) (Fig. 1).

\subsubsection{Sample preparation}

1. Prepare LecA solution from the lyophilised protein powder (approx. $2 \mathrm{mg}$ ) from subsection 3.1.3 in milliQ water supplemented with $0.1 \mathrm{mM} \mathrm{CaCl}_{2}$ (see Note 8).

2. Centrifuge the solution at $7,000 \times \mathrm{g}(5 \mathrm{~min})$ to remove precipitated protein.

3. Determine the protein concentration in the supernatant in $\mathrm{mg} / \mathrm{mL}$ using absorbance at 280 $\mathrm{nm}$ (absorbance coefficient of LecA is 2.191). The final concentration should be around 10 $\mathrm{mg} / \mathrm{mL}$.

4. Prepare a $50 \mathrm{mM}$ solution of Galactose in milliQ water.

5. Prepare crystallization solution containing $1.5 \mathrm{M}$ ammonium sulphate, $100 \mathrm{mM}$ sodium acetate $\mathrm{pH} 4.7,5 \%$ 2-methyl-2,4-pentanediol (MPD) and 2\% glycerol (1 mL per well).

\subsubsection{Hanging Drop Vapour Diffusion}

1. Add $1 \mu \mathrm{L}$ of $50 \mathrm{mM}$ galactose to $24 \mu \mathrm{L}$ of LecA at $10 \mathrm{mg} / \mathrm{mL}$ and incubate for 1 hour at room temperature (see Note 9).

2. Aliquots $1 \mathrm{~mL}$ of the crystallisation solution into a 24 wells crystallisation plate.

3. Mix $1 \mu \mathrm{L}$ of protein-ligand solution from 3.3.1 with $1 \mu \mathrm{L}$ of the crystallization solution on a 22-mm cover slip to create a crystallisation drop.

4. Close the well containing crystallisation solution with the cover slip containing the LecAGal drop. Ensure that the drop is hanging inside the well but not in contact with the crystallisation solution. Press gently on the cover slip to ensure good contact between the cover slip and the grease on top of the well.

5. Close the plate lid and store the plate at $19{ }^{\circ} \mathrm{C}$. Monitor the formation of protein crystals every 2-3 days until the crystals are formed.

\section{Notes}

1. LecA is a calcium-dependent lectin and it is advised to maintain a $\mathrm{CaCl}_{2}$ concentration of $100 \mu \mathrm{M}$ throughout the purification and the SPR experiment. If needed, this concentration can be decreased to $10 \mu \mathrm{M}$.

2. LecA can also be crystallised using PEG as a precipitant. For example, the crystallisation conditions for LecA in complex with melibiose ( $\alpha \mathrm{Gal1}-6 \mathrm{Glc})$ is 15\% PEG $5000 \mathrm{MME}$, $100 \mathrm{mM} \mathrm{KSCN}, 100 \mathrm{mM}$ sodium acetate $\mathrm{pH} 4.6$ [21]. The favourite crystallization $\mathrm{pH}$ is 4.6 but some crystals can also be obtained at basic $\mathrm{pH}$ with $100 \mathrm{mM}$ Tris 8.5.[18]

3. LecA is a very robust protein that can be lyophilised and stored at $-20{ }^{\circ} \mathrm{C}$ for months or years. It is only recommended to aliquot in small quantities to avoid defreezing and refreezing.

4. Preparation of LecA in acetate buffer $\mathrm{pH} 4.5$ is required to ensure that the protein is positively charged (theoretical pI of LecA is 5.04), allowing electrostatic interaction with the negatively charge on the chip surface, which provides efficient means for concentrating positively charged protein on the surface. However, LecA has limited stability in the acetate buffer and therefore the protein solution should be prepared as shortly as possible before injection.

5. For a perfect SPR measurement, the main recommendation is to avoid buffer mismatch by using the running buffer to prepare the analyte solution. It is strongly advised not to use organic buffering agent such as HEPES during chip activation and LecA fixation because the organic agent could react with the activated surface.

6. NHS/EDC mixture should be mixed shortly before injection. 
7. For the evaluation of the binding response, the BIACORE system automatically performs reference subtraction, where the absolute response of the active flow cell (flow cell containing immobilised LecA) is subtracted by that recorded on the reference flow cell (the flow cell without LecA). During data analysis such as kinetic and affinity determination, double referencing is also performed, where reference subtraction, as well as the subtraction of blank injections (zero analyte concentrations) are performed.

8. LecA can also be prepared in $20 \mathrm{mM}$ Tris-HCl or HEPES-NaOH pH 7.5 supplemented with $0.1 \mathrm{mM} \mathrm{CaCl}_{2}$ for ligands that to be in basic solution.

9. LecA ligand can also be added to the crystallization solutions instead of to the protein solution but it requires much more ligand and is not recommended for precious ligand.

\section{Acknowledgements}

The authors acknowledge support by the ANR PIA Glyco@Alps (ANR-15-IDEX-02), Labex ARCANE and CBH-EUR-GS (ANR-17-EURE-0003), and the french cystic fibrosis association Vaincre la Mucoviscidose.

\section{References}

1. Lyczak J B, Cannon L, Pier G B (2002) Lung infection associated cystic fibrosis. Clin Microbiol Rev. 15:194-222

2. Gilboa-Garber N (1982) Pseudomonas aeruginosa Lectins. Methods Enzymol. 83:378385

3. Winzer K, Falconer C, Garber N et al. (2000) The Pseudomonas aeruginosa Lectins PA-IL and PA-IIL Are Controlled by Quorum Sensing and by RpoS. J Bacteriol. 182:6401-6411

4. Glick J, Garber N (2009) The intracellularl localization of Pseudomonas aeruginosa lectins. Microbiology. 129:3085-3090

5. Diggle S P, Stacey R E, Dodd C et al. (2006) The galactophilic lectin, LecA, contributes to biofilm development in Pseudomonas aeruginosa. Environ Microbiol. 8:1095-1104

6. Chemani C, Imberty A, De Bentzmann S et al. (2009) Role of LecA and LecB lectins in Pseudomonas aeruginosa-induced lung injury and effect of carbohydrate ligands. Infect Immun. 77:2065-2075

7. Laughlin R, Musch M , Hollbrook, C et al. (2000) The key role of Pseudomonas aeruginosa PA-I lectin on experimental gut-derived sepsis. Ann Surg. 232:133-142

8. Zheng S, Eierhoff T, Aigal S et al. (2017) The Pseudomonas aeruginosa lectin LecA triggers host cell signalling by glycosphingolipid-dependent phosphorylation of the adaptor protein CrkII. Biochim Biophys Acta - Mol Cell Res. 1864:1236-1245

9. Eierhoff T, Bastian B, Thuenauer R et al. (2014) A lipid zipper triggers bacterial invasion. Proc Natl Acad Sci. 111:12895-12900

10. Blanchard B, Nurisso A, Hollville E et al. (2008) Structural basis of the preferential binding for globo-series glycosphingolipids displayed by Pseudomonas aeruginosa lectin I. J Mol Biol. 383:837-853

11. Kadam R, Garg D, Schwartz J et al. (2013) $\mathrm{CH}-\pi$ "T-Shape" Interaction with Histidine Explains Binding of Aromatic Galactosides to Pseudomonas aeruginosa Lectin LecA. ACS Chem Biol. 8:1925-1930

12. Cioci G, Mitchell E, Gautier C et al. (2003) Structural basis of calcium and galactose recognition by the lectin PA-IL of Pseudomonas aeruginosa. FEBS Lett. 555:297-301

13. Rodrigue J, Ganne G, Blanchard B et al. (2013) Aromatic thioglycoside inhibitors against the virulence factor LecA from Pseudomonas aeruginosa. Org Biomol Chem. 11:6906 
14. Kadam R, Bergmann M, Hurley M et al. (2011) A glycopeptide dendrimer inhibitor of the galactose-specific lectin LecA and of Pseudomonas aeruginosa biofilms. Angew Chemie Int Ed. 50:10631-10635

15. Visini R, Jin X, Bergmann, M et al. (2015) Structural insight into multivalent falactoside binding to Pseudomonas aeruginosa lectin LecA. ACS Chem Biol. 10:2455-2462

16. Cecioni S, Lalor R, Blanchard B et al. (2009) Achieving High Affinity towards a Bacterial Lectin through Multivalent Topological Isomers of Calix[4]arene Glycoconjugates. Chem - A Eur J. 15:13232-13240

17. Cecioni S, Praly JP, Matthews, S et al. (2012) Rational Design and Synthesis of Optimized Glycoclusters for Multivalent Lectin-Carbohydrate Interactions: Influence of the Linker Arm. Chem - A Eur J. 18:6250-6263

18. Novoa A, Eierhoff T, Topin J et al. (2014) A LecA ligand identified from a galactoside-conjugate array inhibits host cell invasion by Pseudomonas aeruginosa. Angew Chemie Int Ed. 53:8885-8889

19. Bergmann M, Michaud G, Visini R et al. (2015) Multivalency effects on Pseudomonas aeruginosa biofilm inhibition and dispersal by glycopeptide dendrimers targeting lectin LecA. Org Biomol Chem. 14:138-148

20. Wagner S, Hauck D, Hoffmann M et al. (2017) Covalent Lectin Inhibition and Application in Bacterial Biofilm Imaging. Angew Chemie - Int Ed. 56:16559-16564

21. Blanchard, B, Imberty, A, and Varrot, A (2014) Secondary sugar binding site identified for LecA lectin from Pseudomonas aeruginosa. Proteins Struct Funct Bioinforma. 82:1060-1065

22. Duverger E, Frison N, Roche, AC et al. (2003) Carbohydrate-lectin interactions assessed by surface plasmon resonance. Biochimie. 85:167-179

23. Cecioni S, Faure S, Darbost U et al. (2011) Selectivity among two lectins: Probing the effect of topology, multivalency and flexibility of "clicked" multivalent glycoclusters. Chem - A Eur J. 17:2146-2159 